\title{
NOTE
}

\section{An infectious hematopoietic necrosis epizootic in sockeye salmon Oncorhynchus nerka in Weaver Creek spawning channel, Fraser River system, B.C., Canada}

\author{
G. S. Traxler, J. B. Rankin
}

Department of Fisheries and Oceans, Biological Sciences Branch, Pacific Biological Station, Nanaimo, British Columbia V9R 5K6, Canada

\begin{abstract}
An epizootic in sockeye salmon Oncorhynchus nerka fry caused by infectious hematopoietic necrosis (IHN) virus occurred in 1987 in the Weaver Creek spawning channel, British Columbia, Canada. The prevalence of IHN virus in a sockeye fry was highest during the early part of fry migration from the spawning channel. Losses of migrating fry were estimated by holding fry for $4 \mathrm{~d}$ periods sequentially throughout the migration and observing mortalities. Of the 16.8 million fry migrating from the channel, an estimated 8.3 million likely died of IHN within days of leaving the spawning chànel.
\end{abstract}

Spawning channels have been used in place of traditional hatcheries in B.C., Canada, for increasing the production of sockeye salmon Oncorhynchus nerka fry (Andrew \& Geen 1960, West 1978). Production of fry in spawning channels eliminates many of the rearing problems associated with hatcheries, and the ability to control water flows, gravel size, and adult spawning density in channels has resulted in higher egg-to-fry survival rates than observed in naturally produced fry. When fry have developed to the swim-up stage, they emerge from the gravel and migrate from the spawning channel to a lake where they rear for 1 or 2 yr prior to migrating to sea.

Weaver Creek is located in the lower Fraser River system, ca $100 \mathrm{~km}$ upstream from the sea (Fig. 1). A spawning channel for sockeye salmon was constructed on the creek and began operating in 1965. From 1965 to 1976 egg-to-fry survival in the spawning channel averaged $76 \%$. However, after 1976, survival rates declined (Fig. 2) and averaged $45 \%$ between 1977 and 1986 (Rosberg et al. 1986).

Returning adult sockeye salmon are diverted from Weaver Creek to the spawning channel. When adequate numbers are in the channel, excess sockeye salmon are allowed to spawn in Weaver Creek above the spawning channel.

In 1974 and 1976, infectious hematopoietic necrosis
(IHN) virus was detected in adult sockeye salmon from the spawning channel. Channel-produced fry from the 1979 brood year suffered losses in April 1980 which were attributed to IHN (G. E. Hoskins pers. comm.).

During the spawning period in 1986, adult sockeye salmon deposited an estimated 84.7 million eggs in the channel (V. Ewert pers. comm.). This was expected to result in the production of 50 to 60 million migrating fry. In March 1987, fry were noticed leaving the gravel at least 3 wk earlier than in previous years. Large numbers of dead and dying fry were observed accumulating along the channel's banks and in back eddies. Most of the fry had a considerable amount of yolk yet to be absorbed because they were still about 100 accumulated Celcius thermal units (ACTU's) from swim-up. Fry moving during the day had an unusual iridescent coloration, considered a sign of IHN by Mulcahy et al. (1983a). Small drops of oil were observed bursting on the surface of the water, likely from ruptured yolk sacs of fry in the gravel. Based on the species, coloration, age of the fish affected, their early emergence from the gravel, and the rapid high losses, IHN was suspected. This study confirms that the excessive losses were due to IHN virus and documents the importance that IHN can have on sockeye fry production from spawning channels.

Materials and methods. Virus assays were performed on individual fry, and viral titers were calculated as plaque forming units (PFU) per gram of whole fish. The plaque assay method of Burke and Mulcahy (1980) was followed using the epithelioma papillosum cyprini (EPC) cell line. A plaque reduction assay using monoclonal anti-IHN virus antibody (in $10 \%$ fetal calf serum) provided by K. Lannan, Oregon State University, was used to confirm the virus as IHN. A $1: 40$ dilution of monoclonal antibody in Dulbecco's phos- 


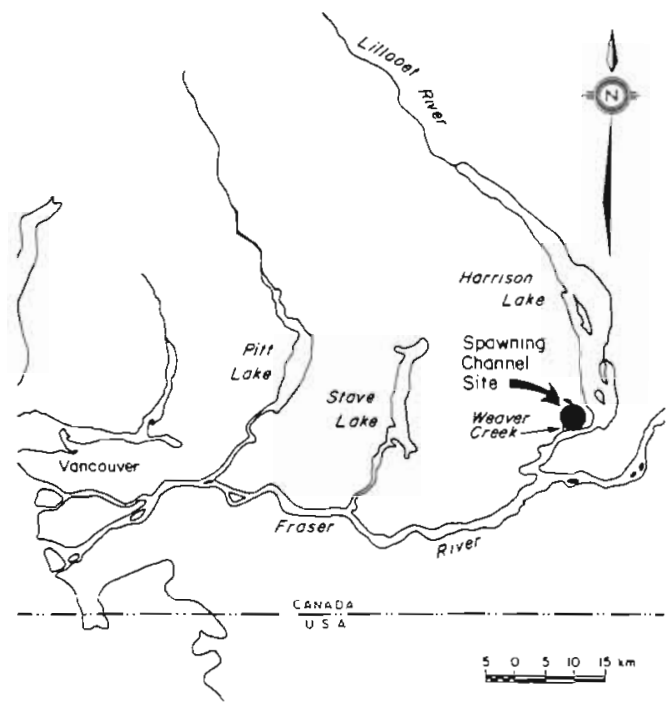

Fig. 1. Location of Weaver Creek spawning channel

phate buffered saline resulted in a $2 \log _{10}$ reduction of plaques when mixed with the virus isolate for $30 \mathrm{~min}$.

Fry collected for histological examination were placed in Bouins' fixative. After being embedded in paraffin, $5 \mu \mathrm{m}$ sections were prepared, stained with hematoxylin and eosin ( $\mathrm{H} \& \mathrm{E}$ ) and examined microscopically. Kidney imprints of moribund fry were stained with Diff-Quik (Dade Diagnostics, Inc. Aguada, Puerto Rico 00602)

Sockeye fry, for virus assays and histology, were randomly collected from the spawning channel throughout the entire fry migration period. Samples of fry were removed each night during the regular fry enumeration program and stored at $-85^{\circ} \mathrm{C}$ until assayed. Forty-eight sockeye fry were also collected from Weaver Creek and assayed individually for the presence of IHN virus

Estimates of mortality occurring in the fry following their departure from the spawning channel were based upon the mortalities observed in migrating fry held for $4 \mathrm{~d}$ in a net enclosure placed in the spawning channel. Sequentially, throughout the migration, 200 fry were held in these enclosures and the mortalities recorded. Representative samples of dead fry, collected from the enclosures, were pooled and assayed for the presence of IHN virus.

Results. The likely cause of fry losses was IHN. The identity of the causative virus, which was found repeatedly in dead and moribund specimens, was confirmed serologically. In addition, the histopathology was consistent with this diagnosis. Giemsa-stained kidney imprints from moribund fry revealed numerous fragments of nuclear and cytoplasmic debris (Fig. 3). These cellular fragments in the kidneys of moribund fish have been used as presumptive evidence for IHN

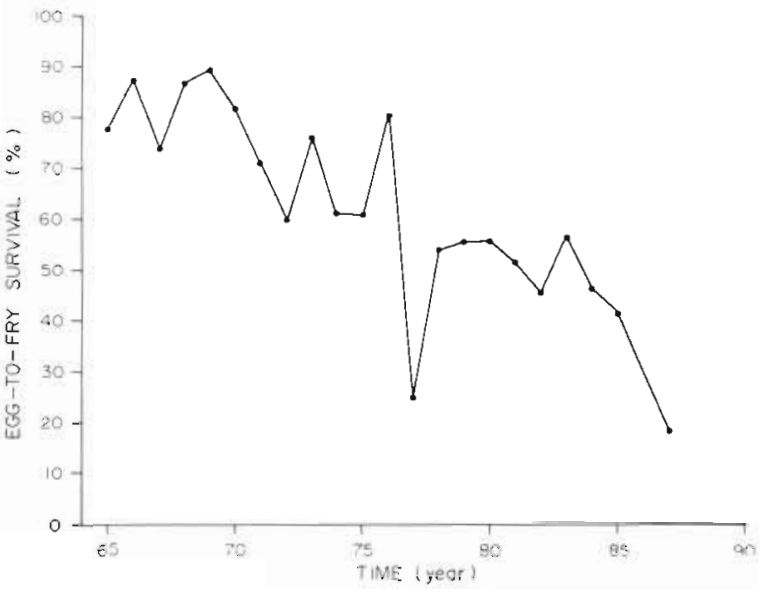

Fig. 2. Oncorhynchus nerka. Egg-to-migrating sockeye fry survival at Weaver Creek spawning channel from 1965 to 1986 (from Rosberg et al. 1986)

(Smith et al. 1972). Microscopic examination of stained sections of 11 moribund fry, collected from the channel during migration, revealed extensive kidney necrosis typical of IHN. Damage to the hematopoietic tissue was so extensive that kidney tubules were often surrounded only by erythrocytes (Fig. 4). All 8 fry collected randomly on the same day as the moribund fry exhibited some degree of kidney necrosis. In 3 of the 8 , necrosis was focal and less severe than the lesions in the other 5 fry (Fig. 5). Both moribund and randomly collected fry had substantial gill damage. Epithelial cells in the gills exhibited necrosis and cellular debris similar to that occurring in the kidney (Fig. 6).

The prevalence of IHN virus in migrating Weaver Creek sockeye fry was highest during the first portion of the run from March 11 to 25, with nearly $100 \%$ of the fry assayed being infected (Table 1). As the run progressed, the prevalence of IHN in the population decreased. Viral titers of individual fish also decreased over the migration period, as indicated by the drop in mean viral titers with time. No virus was isolated from a parallel sample of 48 fry assayed without holding from the Weaver Creek population.

Sockeye fry from the early portion of the migration underwent high losses when trapped and held for a $4 \mathrm{~d}$ period (Fig. 7). Fry captured and held during the middle and latter part of the migration suffered progressively lower losses.

Discussion. Several cases of IHN have been reported in natural populations of sockeye salmon and kokanee (non-anadromous form of sockeye salmon; Williams \& Amend 1976. Burke \& Grischkowsky 1984, Traxler 1986) but these reports give little, if any, information on the prevalence of the virus and the distribution of mortalities during IHN outbreaks. 

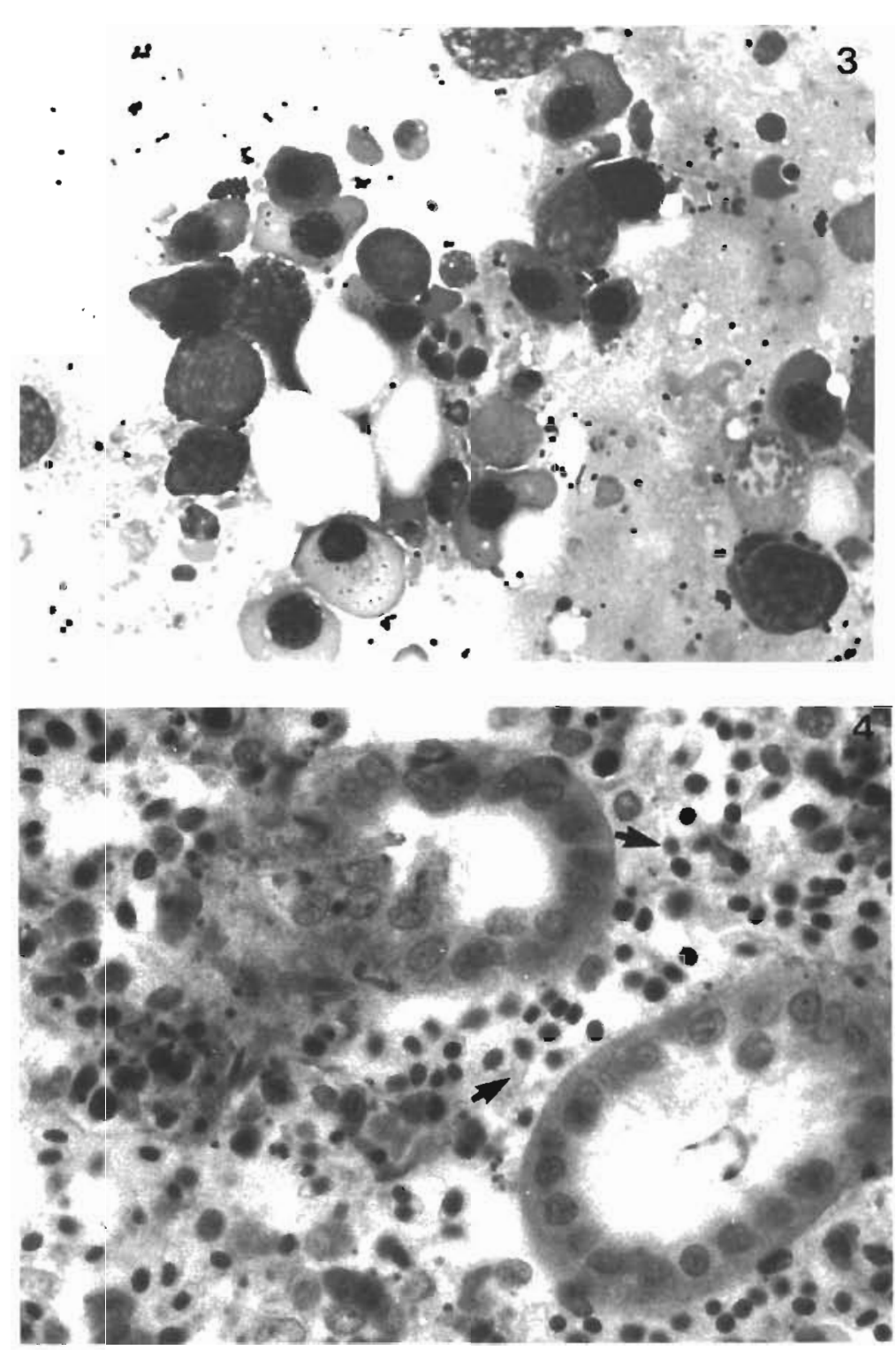

Fig. 3. Oncorhynchus nerka. Kidney imprint from moribund sockeye fry showing cellular fragments $(\times 825)$
The operation of sockeye spawning channels where fry emerge from the gravel and leave the channel for rearing in lakes leaves little opportunity to observe their survival. Fry debilitated by disease are likely to be removed from the population by predators. It is not possible to duplicate, experimentally, the actual environmental conditions experienced by migrating fry. However, holding small groups of fry with minimal handling stress for short periods of time should provide some indication of the fry survival that might be expected following their departure from the spawning channel. It has been demonstrated that the first mortalities of fry challenged by waterborne exposure to IHN virus occur after $4 \mathrm{~d}$ (Wingfield 1968, Hedrick et al. 1987). Therefore, losses that occurred within the $4 \mathrm{~d}$ holding period were likely fry that had acquired their
IHN infection prior to capture. We confirmed that fry dying during the holding period did so of IHN.

Fish undergoing losses due to IHN usually have viral titers in excess of $10^{4}$ PFU $\mathrm{g}^{-1}$ of tissue (Mulcahy et al. 1983a, Burke \& Grischkowsky 1984, Traxler 1986). The amount of IHN virus required to kill a fish is likely dependent upon the species, age, physiological state, and environmental conditions. However, results obtained in this laboratory (Traxler unpubl.) have indicated that mortalities of sockeye fry can occur when viral titers as low as $10^{4} \mathrm{PFU}^{-1}$ of whole fish are reached. This was confirmed in the present study in the mortality patterns of fry held at different times during the migration. Mortalities decreased dramatically, but did not end, when the mean viral titer dropped to $10^{4}$ PFU $g^{-1}$. 

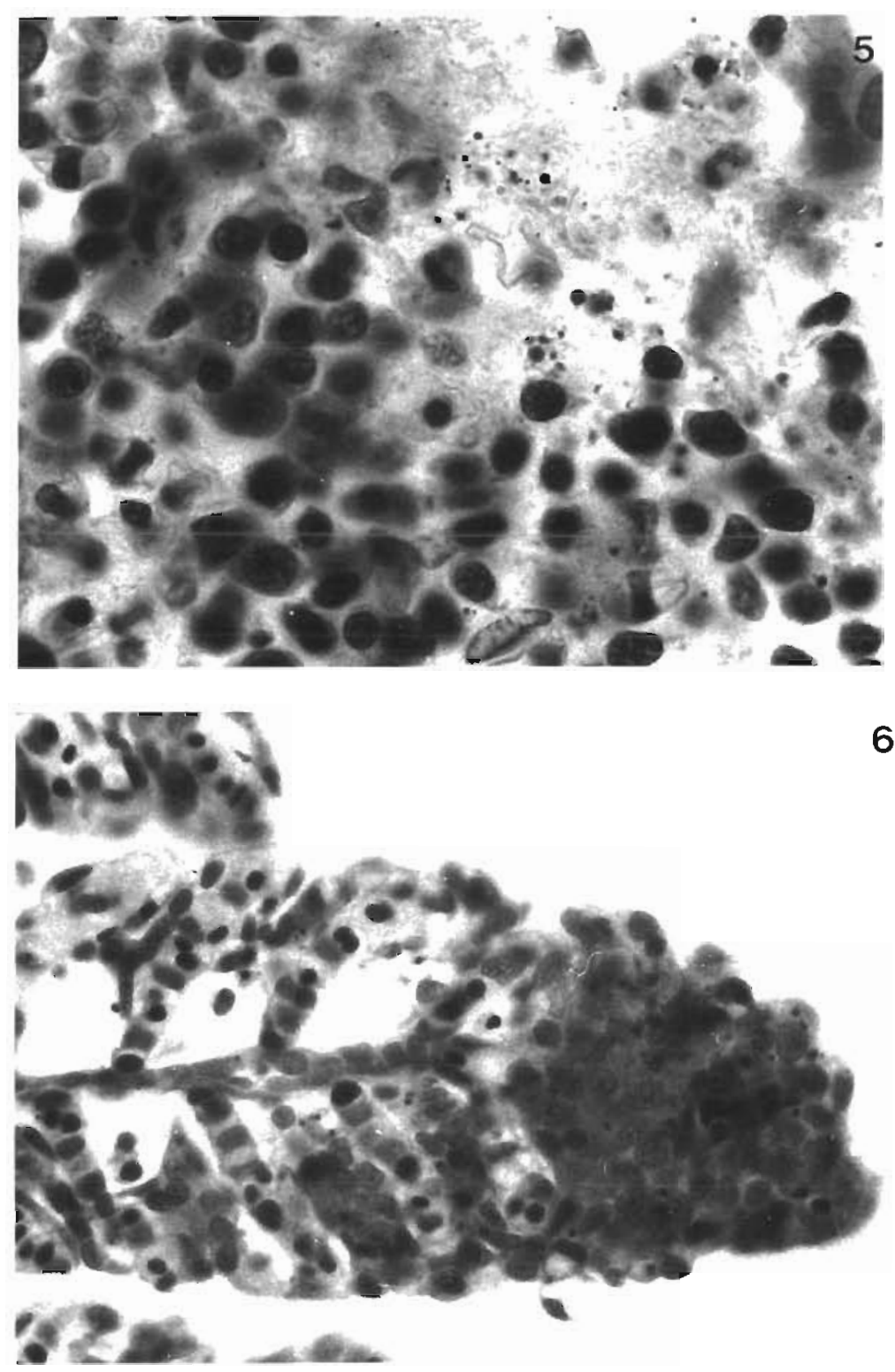

Fig. 5. Oncorhynchus nerka. Section of kidney from a randomly sampled sockeye fry showing areas of focal necrosis $(\times 825)$
During the period of fry migration an estimated 16.8 million fry moved out of the spawning channel into the lake, resulting in an egg-to-migrating fry survival of $19.6 \%$. (V. Ewert pers. commun.). This was the lowest egg-to-fry survival ever recorded at the Weaver Creek spawning channel. Based upon mortalities observed in captive fry, an estimated 8.3 million of migrating fry probably died of IHN within a few days of leaving the spawning channel.

The absence of IHN virus-infected fry in samples from Weaver Creek is unusual and may have been partly due to the smaller sample obtained. Infected fry in the creek, where egg-to-fry survival has averaged $6.9 \%$ (V. Ewert pers comm.), would likely largely be removed by predators by the time they reached the
Fig. 6. Oncorhynchus nerka. Gill section of IHNinfected fry with necrotic epithelial cells $(\times 400)$
6

sampling site, because the main spawning area was several $\mathrm{km}$ upstream of the sampling site. Also, waterborne transmission of IHN in Weaver Creek would likely have been less efficient than in the spawning channel where fry densities were higher.

Gills of sockeye salmon have been shown to be an initial site of infection with waterborne IHN virus (Mulcahy et al. 1983 b). The scattered necrotic epithelial cells observed in the gills of IHN-infected fry may have been a result of horizontal transmission of the virus followed by viral replication in this tissue.

Factors that contributed to the epizootic are unknown, but IHN has been documented in both fry and adult sockeye in Weaver Creek spawning channel in previous years (Rosberg et al. 1986). Environmental 
Table 1. Oncorhynchus nerka. IHN virus titers and prevalence in sockeye fry migrating from Weaver Creek and Weaver Creek spawning channel in 1987

\begin{tabular}{|c|c|c|c|c|c|c|c|c|c|c|c|c|}
\hline \multirow[t]{2}{*}{$\begin{array}{l}\text { Date of } \\
\text { migration }\end{array}$} & \multirow[t]{2}{*}{$\begin{array}{l}\text { No. infected/ } \\
\text { no. examined }\end{array}$} & \multirow[t]{2}{*}{$\begin{array}{c}\% \\
\text { infected }\end{array}$} & \multicolumn{9}{|c|}{$\begin{array}{l}\text { IHN virus titer (PFU g }{ }^{-1} \text { whole fish) } \\
\text { No. fish with virus titers between }\end{array}$} & \multirow[t]{2}{*}{$\begin{array}{l}\text { Mean virus } \\
\text { titer }\end{array}$} \\
\hline & & & $n \in g$ & $10^{2}$ & $10^{3}$ & $10^{4}$ & $10^{5}$ & $10^{6}$ & $10^{7}$ & $10^{8}$ & $10^{9}$ & \\
\hline \multicolumn{13}{|l|}{ Channel } \\
\hline Mar 11 & $80 / 80$ & 100 & & & & & & 1 & 22 & 53 & 4 & $3.7 \times 10^{8}$ \\
\hline Mar 14 & $10 / 10$ & 100 & & & & & 1 & 4 & 5 & & & $1.1 \times 10^{7}$ \\
\hline Mar 15 & $10 / 10$ & 100 & & & & & & & 9 & 1 & & $4.8 \times 10^{7}$ \\
\hline Mar 17 & $10 / 10$ & 100 & & & & & & 1 & 7 & 2 & & $5.5 \times 10^{7}$ \\
\hline Mar 18 & $10 / 10$ & 100 & & & & & & & 10 & & & $6.2 \times 10^{7}$ \\
\hline Mar 19 & $10 / 10$ & 100 & & & & 1 & & 1 & 7 & 1 & & $5.9 \times 10^{7}$ \\
\hline Mar 23 & $8 / 10$ & 80 & 2 & 1 & 3 & & 1 & & 2 & 1 & & $1.9 \times 10^{7}$ \\
\hline Mar 24 & $10 / 10$ & 100 & & & 2 & 1 & 3 & 1 & 3 & & & $3.2 \times 10^{6}$ \\
\hline Mar 25 & $10 / 10$ & 100 & & & 3 & 2 & 1 & & 4 & & & $2.2 \times 10^{7}$ \\
\hline $\operatorname{Mar} 26$ & $1 / 10$ & 10 & 9 & & & & 1 & & & & & $2.6 \times 10^{4}$ \\
\hline $\operatorname{Mar} 27$ & $3 / 10$ & 30 & 7 & & 2 & & 1 & & & & & $1.0 \times 10^{4}$ \\
\hline Mar 29 & $3 / 10$ & 30 & 7 & & 1 & 1 & 1 & & & & & $1.2 \times 10^{4}$ \\
\hline Mar 30 & $3 / 10$ & 30 & 7 & & & & 3 & & & & & $5.4 \times 10^{4}$ \\
\hline Apr 3 & $2 / 10$ & 20 & 8 & & & 2 & & & & & & $7.9 \times 10^{3}$ \\
\hline Apr 10 & $0 / 10$ & 0 & 10 & & & & & 1 & & & & 0 \\
\hline Apr 14 & $1 / 10$ & 10 & 9 & & & & & & & & & $1 \times 10^{5}$ \\
\hline Apr 16 & $1 / 10$ & 10 & 9 & & & & 1 & & & & & $4.1 \times 10^{4}$ \\
\hline \multicolumn{13}{|l|}{ Creek } \\
\hline Mar 18 & $0 / 10$ & 0 & 10 & & & & & & & & & 0 \\
\hline Mar 18 & $0 / 10$ & 0 & 10 & & & & & & & & & 0 \\
\hline Mar 19 & $0 / 18$ & 0 & 18 & & & & & & & & & 0 \\
\hline Apr 8 & $0 / 10$ & 0 & 10 & & & & & & & & & 0 \\
\hline
\end{tabular}

conditions, such as water flow, oxygen level, temperature, lack of ice formation, and lack of algal growth, appeared favorable for both egg and fry survival during the 1986 broodyear (V. Ewert pers. comm.). Stress, density, water quality, and diets have been shown to be important factors in the susceptibility of fish to disease, expecially in hatcheries (Wedemeyer 1970. Wedemeyer \& Ross 1973, Wood 1974, Sanders et al. 1978).
Factors important in disease outbreaks in natural or spawning channel-enhanced fish stocks are less well understood. This study has demonstrated that IHN can account for substantial losses in sockeye salmon fry in a spawning channel. These losses can occur both within the channel prior to outmigration of the fry, and as deduced from this study, after the fry have left the channel. The construction of spawning channels to

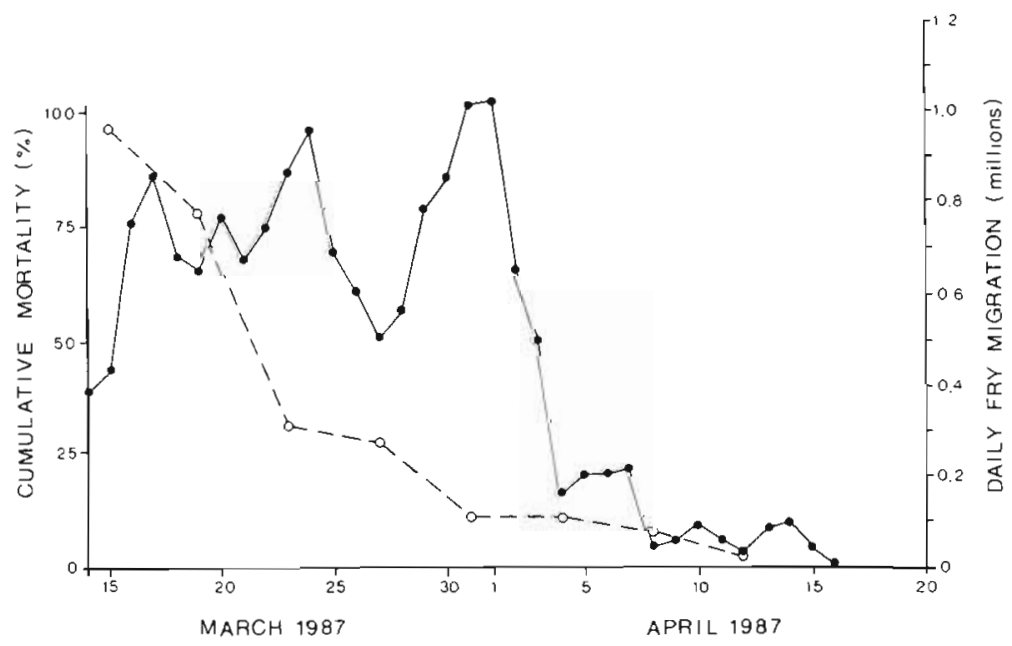

Fig. 7. Oncorhynchus nerka. Cumulative mortality rates of sockeye fry held for $4 \mathrm{~d}$ periods during fry migration (O), and daily migration of sockeye fry from spawning channel 
increase sockeye fry production can result in disease problems which are difficult to control. However, increased knowledge of the epizootiology of IHN virus in sockeye populations should lead to measures that will reduce these losses.

Acknowledgements. We thank $V$ Ewert, manager of Weaver Creek spawning channel, for collecting sockeye fry during the migration period and monitoring holding losses, and Dr L. Margolis for reviewing the manuscript.

\section{LITERATURE CITED}

Andrew, F. J., Geen, G. H. (1960). Sockeye and pink salmon production in relation to proposed dams on the Fraser Rivel systen. internationa l Pacific Salmon Fisheries Commission Bulletin XI

Burke, J., Grischkowsky R. (1984). An epizootic caused by infectious hematopoietic necrosis virus in an enhanced population of sockeye salmon, Oncorhynchus nerka (Walbaum), smolts at Hidden Creek, Alaska. J. Fish Dis. 7: $421-429$

Burke, J., Mulcahy, D. (1980). Plaquing procedure for infectious hematopietic necrosis virus. Appl. envirl Microbiol. 39 $872-876$

Hedrick, R. P., LaPatra, S. E., Fryer, J. L., McDowell, T., Wingfield, W. H. (1987). Susceptibility of coho (Oncorhynchus kisutch) and chinook (Oncorhynchus tshawytscha) salmon hybrids to experimental infections with infectious hematopoietic necrosis virus (IHNV). Bull. Eur. Ass. Fish. Path. 7 (4): 97-100

Mulcahy, D., Pascho, R., Jenes, C. K. (1983 a). Mortality due to infectious hematopoietic necrosis of sockeye salmon (Oncorhynchus nerka) fry in streamside egg incubation boxes. Can. J. Fish aquat. Sciences 40: 1511-1516

Mulcahy, D., Pascho, R. J., Jenes, C. K. (1983 b). Detection of infectious hematopoietic necrosis virus in river water and demonstration of waterborne transmission. J. Fish Dis. 6 : 321-330

Rosberg, G. E., Scott K. J., Rithaler, R. (1986) Review of the International Pacific Salmon Fisheries Commission's sockeye and pink salmon enhancement facilities on the Fraser River. Dept. of Fisheries and Oceans, Vancouver, B, C.

Sanders, J. E., Pilcher, K. S., Fryer, J. L. (1978). Relation of water temperature to bacterial kidney disease in coho salmon (Oncorhynchus kisutch), sockeye salmon (O. nerka), and steelhead trout (Salmo gairdneri). J. Fish. Res. Bd Can. 35: 8-11

Smith, C. E., Yasutake, W T., Amend, D. F. (1972). Morphological changes in the blood of salmonids during natural and experimental infections with IHN virus. U. S. Fish and Wildlife Service, Bozeman, Montana (unpublished report)

Traxler, G. S. (1986). An epizootic of infectious hematopoietic necrosis in 2-year-old kokanee, Oncorhynchus nerka (Walbaum) at Lake Cowichan, British Columbia. I. Fish Dis, 9: 545-549

Wedemeyer, G. A. (1970). The role of stress in the disease resistance of fisches. In: Snieszko, S. F., (Ed.) A. symposium on diseases of fishes and shellfishes. Am. Fish. Soc., Spec. Publ. No. 5., p. 30-35

Wedemeyer, G. A., Ross, A. J. (1973). Nutritional factors in the biochemical pathology of corynebacterial kidney disease in the coho salmon (Oncorhynchus kisutch). J. Fish. Res Bd Can. 30: 296-298

West, C. J. (1978). A review of the Babine Lake development projekt 1961-1977. Fisheries and Marine Service Technical Rept. 812

Williams, I., Amend, D. F. (1976). A natural epizootic of infectious hematopoietic necrosis in fry of sockeye salmon (Oncorhynchus nerka) at Chilko Lake, British Columbia. J. Fish. Res. Bd Can. 33: 1564-1567

Wingfield, H. W. (1968). Characterization of the Oregon sockeye salmon virus. Ph. D. thesis, Oregon State University

Wood, J. W. (1974 2nd ed). Diseases of Pacific salmon, their prevention and treatment. Washington Department of Fisheries, Hatchery Division, Olympia, Washington 